\title{
Hypothyroidism and growth failure in diabetes mellitus
}

\author{
S COURT AND J M PARKIN
}

Department of Child Health, Royal Victoria Infirmary, Newcastle upon Tyne

SUMMARY The prevalence of thyroid disease in 134 children, adolescents, and young adults with diabetes mellitus beginning in childhood is described. Clustering of a family history of thyroid disease and the presence of thyrogastric antibodies in some patients supports the concept of familial autoimmunity. In 4 children a diagnosis of hypothyroidism had already been made, one of whom had shown marked faltering of growth. In a further 3 there was evidence of previously unrecognised subclinical hypothyroidism but the growth of 2 of them had been good. The findings of this study indicate that while subclinical hypothyroidism should be considered in a diabetic whose growth is faltering, it is rarely a cause of such growth failure.

There is an association between diabetes mellitus and autoimmune thyroid disease; often thyroid antibodies are present in diabetic patients ${ }^{12}$ and carbohydrate intolerance has been shown in children with autoimmune thyroiditis. ${ }^{3}$ Recent evidence suggests that autoimmunity is of aetiological importance in a subgroup of juvenile diabetics in which antibodies are present both in the patients and their families. ${ }^{4}$ It has therefore been advocated that thyroid antibody studies should form part of the initial investigation of diabetics. ${ }^{25}$

Poor growth velocity is common in children with diabetes, ${ }^{67}$ and as this is particularly the case if diabetic control is poor it is generally attributed to the metabolic disturbance of the disease. In this paper we explore the possible role of subclinical hypothyroidism as a cause of the growth retardation.

\section{Patients and methods}

One hundred and thirty-four children and young adults ( 70 male, 64 female) from diabetic clinics in the Northern Health Region were studied. Each had developed diabetes before puberty, was less than 20 years of age, and had been under regular review for at least 2 years.

Standard haemagglutination and immunofluorescence methods were used to demonstrate the presence of thyroid globulin, thyroid microsomal, and gastric parietal cell antibodies. A minimum titre of $1: 20$ for thyroid globulin and 1:100 for thyroid microsomal antibodies was accepted as positive, parietal cell antibodies being reported as either present or absent. Thyroid function was assessed by measuring the serum level of thyroid stimulating hormone (TSH) by radioimmunoassay. The bone age was estimated using the 20 bone method of Tanner et al. ${ }^{8}$ Quality of growth was determined by change in height standard deviation (SD) score during the whole of the child's diabetic life where height $\mathrm{SD}$ score $=\mathrm{X}-\overline{\mathrm{X}} / \mathrm{SD}$.

$$
\begin{aligned}
\mathrm{X}= & \text { child's height } \\
\overline{\mathrm{X}}, \mathrm{SD}= & \text { mean and standard devi- } \\
& \text { ation appropriate for age } \\
& \text { and sex. }{ }^{9}
\end{aligned}
$$

On the basis of this measurement growth was categorised as good if the change was positive, fair if it was less than $-0 \cdot 5$, poor if it was between -0.5 and -1 , and very poor if the change in SD score was greater than -1 .

\section{Results}

The details of 4 children with previously recognised hypothyroidism are presented in Table 1 . One child (Case 2), with a strong family history of goitre, had an ectopic gland confirmed by isotope scan. Cases 3 and 4 were siblings. The brother had developed classical symptoms of diabetes mellitus 2 weeks after his sister had been shown to have both diabetes mellitus and autoimmune thyroiditis. His growth velocity was slow during the 2 years after diagnosis despite advance in puberty (Fig. 1). He was then recognised as having hypothyroidism (TSH 22.7 $\mathrm{mU} / \mathrm{l})$ and when thyroxine was started he began to grow normally. 

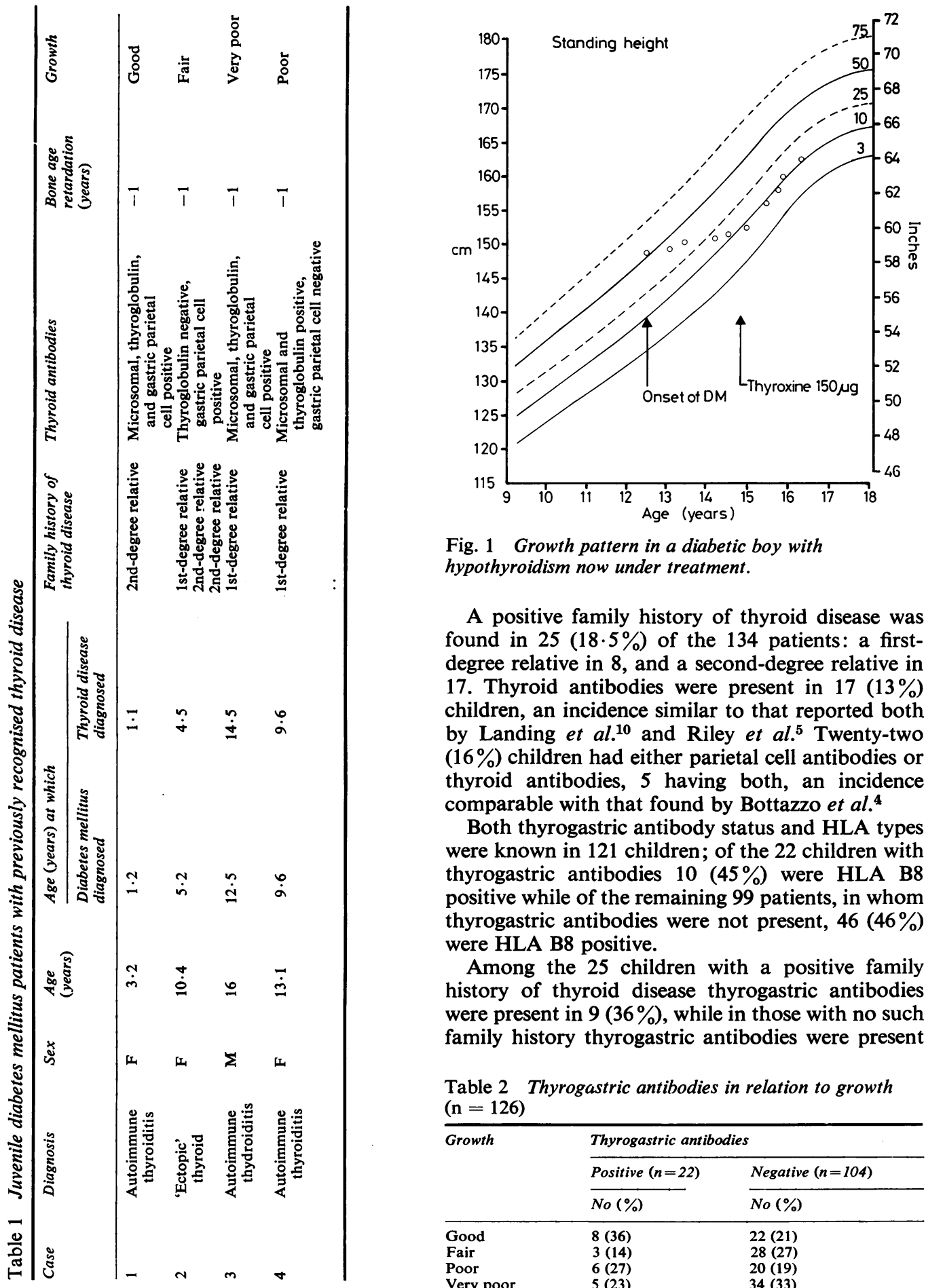

Fig. 1 Growth pattern in a diabetic boy with hypothyroidism now under treatment.

A positive family history of thyroid disease was found in $25(18.5 \%)$ of the 134 patients: a firstdegree relative in 8 , and a second-degree relative in 17. Thyroid antibodies were present in $17(13 \%)$ children, an incidence similar to that reported both by Landing et al. ${ }^{10}$ and Riley et al. ${ }^{5}$ Twenty-two $(16 \%)$ children had either parietal cell antibodies or thyroid antibodies, 5 having both, an incidence comparable with that found by Bottazzo et al. ${ }^{4}$

Both thyrogastric antibody status and HLA types were known in 121 children; of the 22 children with thyrogastric antibodies $10(45 \%)$ were HLA B8 positive while of the remaining 99 patients, in whom thyrogastric antibodies were not present, $46(46 \%)$ were HLA B8 positive.

Among the 25 children with a positive family history of thyroid disease thyrogastric antibodies were present in $9(36 \%)$, while in those with no such family history thyrogastric antibodies were present

Table 2 Thyrogastric antibodies in relation to growth $(\mathrm{n}=126)$

\begin{tabular}{lll}
\hline Growth & \multicolumn{2}{l}{ Thyrogastric antibodies } \\
\cline { 2 - 3 } & Positive $(n=22)$ & Negative $(n=104)$ \\
\cline { 2 - 3 } & No(\%) & No $(\%)$ \\
\hline Good & $8(36)$ & $22(21)$ \\
Fair & $3(14)$ & $28(27)$ \\
Poor & $6(27)$ & $20(19)$ \\
Very poor & $5(23)$ & $34(33)$ \\
\hline
\end{tabular}


Table 3 Juvenile diabetes mellitus patients with thyroid stimulating hormone $>7 \mathrm{mU} / \mathrm{l}$

\begin{tabular}{|c|c|c|c|c|c|c|c|c|}
\hline Case & Sex & $\begin{array}{l}\text { Age } \\
\text { (years) }\end{array}$ & $\begin{array}{l}\text { Age at which } \\
\text { diabetes mellitus } \\
\text { diagnosed }\end{array}$ & $\begin{array}{l}T S H \\
(m U / l)\end{array}$ & $\begin{array}{l}\text { Thyroid } \\
\text { antibodies }\end{array}$ & Family history & $\begin{array}{l}\text { Bone age } \\
\text { retardation } \\
\text { (years) }\end{array}$ & Growth \\
\hline $\begin{array}{l}1 \\
2 \\
3 \\
4 \\
5 \\
6\end{array}$ & $\begin{array}{l}\mathbf{F} \\
\mathbf{M} \\
\mathbf{F} \\
\mathbf{F} \\
\mathbf{F} \\
\mathbf{M}\end{array}$ & $\begin{array}{r}9 \cdot 0 \\
10 \cdot 0 \\
13 \cdot 4 \\
13 \cdot 3 \\
17 \cdot 8 \\
19 \cdot 9\end{array}$ & $\begin{array}{r}1 \cdot 2 \\
4 \cdot 1 \\
11 \cdot 3 \\
7 \cdot 0 \\
4 \cdot 5 \\
1 \cdot 8\end{array}$ & $\begin{array}{r}13 \cdot 7 \\
7 \cdot 0 \\
8 \cdot 2 \\
7 \cdot 4 \\
10 \cdot 6 \\
7 \cdot 4\end{array}$ & $\begin{array}{l}\text { Positive } \\
\text { Negative } \\
\text { Positive } \\
\text { Negative } \\
\text { Positive } \\
\text { Negative }\end{array}$ & $\begin{array}{l}\text { 2nd-degree relative } \\
\text { Negative } \\
\text { Negative } \\
\text { Negative } \\
\text { 2nd-degree relative } \\
\text { Negative }\end{array}$ & $\begin{array}{r}<-1 \\
-1 \cdot 5 \\
-1 \cdot 2 \\
-1 \cdot 7 \\
-2 \cdot 5 \\
\text { Adult }\end{array}$ & $\begin{array}{l}\text { Good } \\
\text { Very poor } \\
\text { Good } \\
\text { Very poor } \\
\text { Very poor } \\
\text { Fair }\end{array}$ \\
\hline
\end{tabular}

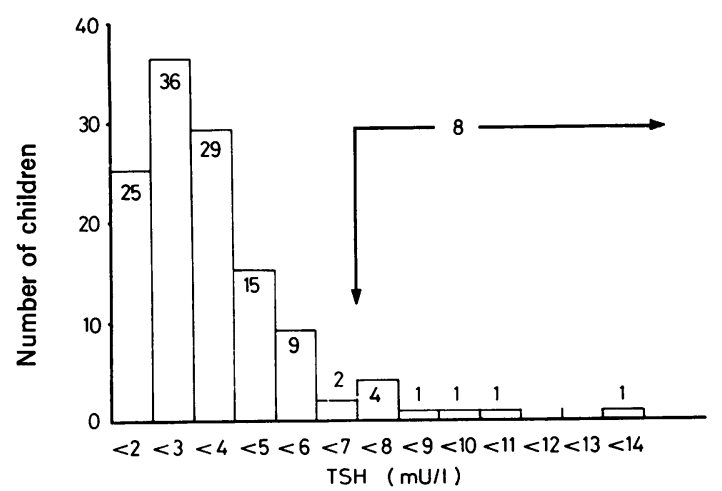

Fig. 2 Serum TSH levels in 124 diabetic children.

in only $13(12 \%)$. The incidence of poor growth was no greater in those with thyrogastric antibodies (Table 2).

The serum TSH levels in 124 patients are shown in Fig. 2. Eight children had levels of $7 \mathrm{mU} / 1$ or more, the accepted upper limit of normal, ${ }^{11}$ and 2 of these were already known to have thyroid disease. Details of the remaining 6 are given in Table 3. Three children (Cases 1, 3, and 5) who had positive thyroid antibodies and levels of TSH greater than $8 \mathrm{mU} / 1$ may be regarded as having subclinical autoimmune hypothyroidism. The two youngest (Cases 1 and 3) had grown well throughout their diabetic life and their growth rate during the year before the study had been 7 and $8.2 \mathrm{~cm}$. In Case 3 this was associated with the onset of puberty. Case 5 was too old for recent growth data to be relevant.

We thank the paediatricians in the Northern Health Region who allowed us to review their patients; the nursing staff on Wards 8 and 16, Royal Victoria Infirmary, Newcastle upon Tyne; Dr T Bird, Dr G Dale, Miss M Goldfinch, Professor D Roberts, and Professor $\mathbf{R}$ Hall for advice and technical support.

S C was supported by a grant from the Research Committee of the Newcastle upon Tyne Area Health Authority (Teaching).

\section{References}

1 Irvine W J, Clarke B F, Scarth L, Cullen D R, Duncan $\mathbf{L} \mathbf{J}$ P. Thyroid and gastric autoimmunity in patients with diabetes mellitus. Lancet 1970; ii: 163-8.

2 Feely J, Isles T E. Screening for thyroid dysfunction in diabetics. Br MedJ 1979; i: 1678.

3 Winter R J, Green O C. Carbohydrate homeostasis in chronic lymphocytic thyroiditis: increased incidence of diabetes mellitus. J Pediatr 1976; 89 : 401-5.

4 Bottazzo G F, Mann J I, Thorogood M, Baum J D, Doniach D. Autoimmunity in juvenile diabetics and their families. $\mathrm{Br}$ Med J 1978; ii: 165-8.

5 Riley W J, Maclaren N K, Lezotte D C, Spillar R P, Rosenbloom A L. Thyroid autoimmunity in insulindependent diabetes mellitus: the case for routine screening. J Pediatr $1981 ; 99: 350-4$.

- Pond H. Some aspects of growth in diabetic children Postgrad Med J 1970; 46: Supplement-September, 616-23.

7 Jivani S K M, Rayner P H W. Does control influence the growth of diabetic children? Arch Dis Child 1973; 48: 109-15.

8 Tanner J M, Whitehouse ' $\mathbf{R}^{\top} \mathbf{H}$, Marshall W A, Healy M J R, Goldstein H. Assessment of skeletal maturity and prediction of adult height (TW2 method). London: Academic Press, 1975.

9 Tanner J M, Whitehouse R H, Takaishi M. Standards from birth to maturity for height, weight, height velocity, and weight velocity: British children, 1965. Part I. Arch Dis Child 1966; 41: 454-71.

10 Landing $B \mathrm{H}$, Pettit $M \mathrm{D}$, Wiens $\mathrm{R} L$, Knowles $\mathrm{H}$, Guest $\mathbf{G}$ M. Antithyroid antibody and chronic thyroiditis in diabetes. J Clin Endocrinol Metab 1963; 23: 119-20.

11 Corcoran J M, Eastman C J, Carter J N, Lazarus L. Circulating thyroid hormone levels in children. Arch Dis Child 1977; 52: 716-20.

Correspondence to Dr S Court, Queen Elizabeth Hospital, Sheriff Hill, Gateshead, Tyne and Wear NE9 6SX.

Received 28 April 1982 